\title{
Price Behaviour of Soybean across Major Markets of Maharashtra
}

\author{
P. C. Tambe*, A. V. Gavali and D. B. Yadav \\ Department of Agril. Economics, MPKV, Rahuri, India \\ *Corresponding author
}

\section{Keywords}

Soybean, ADF test, Co-integration, Granger causality test, Price movement

\section{Article Info}

\section{Accepted:}

22 January 2021

Available Online:

10 February 2021
The soybean (Glycine max) is a species of legume, popularly known as the "golden bean" or "miracle bean" of the $21^{\text {st }}$ century. Soybean is the leading oilseed produced globally. Huge fluctuations in prices of farm produce are observed during past few years. The present study aimed to study price movement of soybean i.e. seasonal variation and co-integration among the major soybean markets in western Maharashtra. For study purpose the data related to monthly average prices and arrivals of soybean were collected from major markets in western Maharashtra state viz., Lasalgaon, Sangali, Kopargaon and Shrirampur for the period 2009-2018. Moving average method used to study seasonal variations. The econometric tools like ADF test, Johansen's multiple co-integration test and Granger causality test model were used study price volatility and co integration among different markets. The results of the study showed that the prices of soybean were higher in the months from June to August in while arrivals of soybean were higher in October to December in all selected markets. For all selected markets the price series showed the consequences of unit root and were stationary at first difference. The selected markets show long run equilibrium relationship and co-integration between them. Most of the markets showed unidirectional influence on soybean prices.

\section{Introduction}

The soybean (Glycine max) is a species of legume, popularly known as the "golden bean" or "miracle bean" of the 21 st century. The plant is classed as an oilseed rather than a pulse. Soybean is an important source of high quality but inexpensive protein and oil. Soybean is the leading oilseed produced globally. India ranks 5th in the list of major soybean producing countries of the world by producing about 3-4 per cent of the global production. Soybean is fastest growing crop in India which replaced the crops like maize, cotton and pulses. Huge fluctuations in prices of farm produce are observed during past few years. The major factors influencing on prices of soybean are the arrivals in market, climatic conditions during the various growth stages, carry forward stocks, price movement over the period of time, crop condition through out the country, export and import, global and 
domestic demand and supply, etc. seasonal variations observed in prices of soybean. In the peak arrivals months the prices of soybean declined while in lean period they rises. The markets of soybean in Maharashtra are cointegrated and they influences on prices of each other.

For better marketing of any agricultural commodity the information regarding seasonality, seasonal variations, price movement across the state and country, etc. is necessary. Analyzing the past trend in the price of commodities is also useful in understanding the present scenario and to formulate appropriate strategies to improve the marketing system.

The study of seasonal variations is considered to be important as a guide to the producer to market his products and to the consumer to purchase his needs at the right time.

It also serves as a guide to the Government to operate its policy measures (procurement and buffer release) at the appropriate time. Therefore, the present study has undertaken with following specific objectives:

To study seasonal variations and cyclical variations in prices of soybean.

To examine the extent and pattern of market integration among the major soybean markets in western Maharashtra.

\section{Materials and Methods}

For study purpose the major soybean markets from the states were selected viz., Lasalgaon, Sangali, Shrirampur and Kopargaon. As per the records available the time series data on monthly average prices and arrivals of soybean for the period from 2008 to 2018 was collected from Maharashtra state agricultural marketing board.

\section{Method of moving average}

The method of moving average most widely used method of measuring seasonal fluctuations and the seasonal indices were used to evaluate seasonal indices.

\section{Cyclical indices}

The most commonly used method for estimating cyclical movement of time series is the residual method by eliminating the seasonal variation and trend is work out cyclical indices.

\section{Estimation of Market Integration}

For examining the integration between the markets the co- integration technique was used. Integrated markets are those markets, where prices were determined interdependently.

To examine the price relationship between two markets, the following basic relationship commonly used to test for the existence of markets integration.

$P i j=a i j+a i P j+E i$

Where, $\mathrm{Pi}$ and $\mathrm{Pj}$ are the price series of a specific commodity in two markets $i$ and $j$.

$\mathrm{E}=$ residual term

Before further analysis, the data is checked for the stationarity of variables. The Augmented Dicky Fuller (ADF) test was used to determine the stationarity of the variables.

\section{Augmented Dickey-Fuller (ADF) unit root test}

An implicit assumption in Johansen's cointegration approach is that the variables should be non-stationary at level, but 
stationary after first differencing. The Augmented Dickey-Fuller test is utilized to check the order of integration by using the model (1):

$\Delta Y_{t}=\propto+\delta T+\beta_{1} Y_{t-1}+\sum_{i=1}^{p} \beta_{1} \Delta Y_{t-1}+\varepsilon_{t} \ldots$.

where, $\Delta Y_{t}=Y_{t}-Y_{t-1}, \Delta Y_{t-1}=Y_{t-1}-Y_{t-2}$, and $\Delta Y_{t-2}=Y_{t-2}-Y_{t-3}$, etc., $\varepsilon_{t}$ is pure white noise term, ${ }^{\propto}$ is the constant-term, $T$ is the time trend effect, and $p$ is the optimal lag value which is selected on the basis of Schwartz Information Criterion (SIC). The null hypothesis is that $\beta_{1}$, the coefficient of $Y_{t-1}$ is zero. The alternative hypothesis is: $\beta_{1}<0$. A non-rejection of the null hypothesis suggests that the time series under consideration is nonstationary.

\section{Co-integration analysis using Johansen procedure}

The Johansen procedure examines a Vector Auto Regressive (VAR) model of $Y t$, an $(n \times$ 1) vector of variables that are integrated of the order one - I (1) time series. This VAR can be expressed as Equation (2):

$\Delta Y_{t}=\mu+\sum_{i=1}^{p-1} \Gamma_{i} Y_{t-1}+\Pi Y_{t-1}+\varepsilon_{t} \ldots$

Where, $\Gamma$ and $\Pi$ are matrices of parameters, $p$ is the number of lags (selected on the basis of Schwarz Information Criterion), $\varepsilon_{t}$ is an $(\mathrm{n} \times 1)$ vector of innovations. The presence of at least one co-integrating relationship is necessary for the analysis of long-run relationship of the prices to be plausible. To detect the number of co-integrating vectors, Johansen proposed two likelihood ratio tests: Trace test and Maximum eigen value test, shown in equations (3) and (4), respectively.

$I_{\text {trace }}=-T \sum_{i=r+1}^{n} \operatorname{In}\left(1-\lambda_{i}^{A}\right)$
$I_{\max }=-\operatorname{TIn}\left(1-\lambda_{i}^{a}+1\right) \ldots \ldots(4)$

Where, $T$ is the sample size and $\lambda_{i}^{\mathrm{A}}$ is the $i^{\text {th }}$ largest canonical correlation. The trace test examines the null hypothesis of $r$ cointegrating vectors against the alternative hypothesis of $n$ co-integrating vectors. The maximum Eigen value test, on the other hand, tests the null hypothesis of $r$ co-integrating vectors against the alternative hypothesis of $r+1$ co-integrating vectors.

\section{Granger causality test}

The Granger Causality test conducted within the framework of a VAR model is used to test the existence and the direction of long-run causal price relationship between the markets. It is an F-test of whether changes in one price series affect another price series. Taking the causality relationship between two wholesale onion markets as an example, the test was based on the following pairs of OLS regression equations through a bivariate VAR:

$\operatorname{PInS}_{t}=\sum_{i=1}^{m} \alpha_{i} \operatorname{PInS}_{t-1}+\sum_{i=1}^{m} \beta_{j} \operatorname{PIn} P_{t-j}+\varepsilon_{1 t} \ldots$.

$P \operatorname{In} P_{t}=\sum_{i=1}^{m} \mathrm{Y}_{i} P \ln P_{t-i}+\sum_{i=1}^{m} \delta_{j} P \operatorname{In} S_{t-j}+\varepsilon_{2 t} \ldots .$.

Where, $S$ and $P$ are Sangali and Kopargaon markets, $P \ln$ stands for price series in logarithm form and $t$ is the time trend variable. The subscript stands for the number of lags of both variables in the system. The null hypothesis in Equation (5), i.e. $H_{0}: \beta_{1}=\beta_{2}$ $=\ldots \ldots . .=\beta_{j}=0$ against the alternative, i.e., $H_{1}$ : Not $H_{0}$, is that $P \ln A_{t}$ does not Granger cause $P \ln D_{t}$. Similarly, testing $H_{0}: \delta_{1}=\delta_{2}=\ldots \ldots .=$ $\delta_{j}=0$ against $H_{1}$ : Not $H_{0}$ in Equation (6) is a test that $P \ln D_{t}$ does not Granger cause $P \ln$ $A_{t}$. In each case, a rejection of the null hypothesis will imply that there is Granger Causality between the variables. 


\section{Results and data analysis}

The findings of the present study as well as relevant discussion have been presented in Fig. 1 to 3 and Table 1 to 5 .

\section{Seasonal variations}

The arrivals of soybean start hitting in the market from the month of October and continue for next five months. The peak period of arrivals is October to December. Due to large arrivals during this period the prices decline. The lean period is from June to September. The prices were recorded higher from April to August. Most of the traders release the stored stock of Soybean during this period in anticipation of making the profit. The seasonal indices of monthly average arrivals and prices of Soybean in Lasalgaon, Sangli, Kopargaon and Shrirampur markets were worked out to study seasonal variations, which are presented in Table 1.

\section{Cyclical variation}

The cyclical indices were worked out for the period 2009-18 and presented in Table 2. The cyclical variations observed in the prices of soybean in the selected markets. The higher prices recorded during the year 2012, 2013, 2014 and 2015. The rise in prices attributed to less production due to bad weather conditions.

\section{Augmented dickey-fuller test (ADF)}

The ADF test is to test for the unit root in a time series. The results of the region wise ADF tests are depicted in Table 3. The Augmented dickey fuller (ADF) based on unit root test procedure is done to check weather soybean prices are stationary in the markets under study. It is revealed from the table that, the critical value $(-3.4865)$ is greater than all the ADF values of first difference in all the selected markets among the different regions of the state indicated that, there existed unit root in these markets. This implies that, the data series in these markets becomes stationary after first difference.

\section{Johansen's multiple co-integration test}

Johansen's multiple co-integration test is employed to determine the long run relationship between the price series. The test shows whether the selected soybean markets are integrated or not. The results of the test presented in Table 4. To test whether the selected soybean markets are integrated or not, Johanson multiple co-integration test conducted by using e-views software and the results were presented in Table 4 . The results of co-integration test showed at least two cointegration equations at 5 per cent level of significance indicated that the selected soybean markets having long run equilibrium relationship and there exists cointegration between them.

\section{Granger causality tests}

In order to know the direction of causation between the markets Granger causality test was employed. When a cointegration relationship is present for two variables, a Granger causality test (Granger, 1969) can be used to analyze the direction of this comovement relationship. Theoretically, a variable is said to Granger-cause another variable, if the current value is conditional on the past value. The casual relationship between the price series of selected soybean markets where approached through Granger causality technique. The results of the analysis showing the relationship between selected soybean markets are presented in Table 5. The unidirectional price influence was seen in Lasalgaon - Kopargaon, Sangali- Kopargaon, Shrirampur-Koprgaon, Sangali-Lasalgaon, Shrirampur-Lasalgaon and shrirampu-sangali market. 
Table.1 Seasonal indices of arrivals and prices of soybean in

Western Maharashtra (2009 to 2018)

\begin{tabular}{|c|c|c|c|c|c|c|c|c|}
\hline \multirow{2}{*}{ Month } & \multicolumn{2}{|c|}{ Lasalgaon } & \multicolumn{2}{c|}{ Sangali } & \multicolumn{2}{c|}{ Kopargaon } & \multicolumn{2}{c|}{ Shrirampur } \\
\cline { 2 - 9 } & $\begin{array}{c}\text { Arriva } \\
\text { ls }\end{array}$ & Prices & $\begin{array}{c}\text { Arriva } \\
\text { ls }\end{array}$ & Prices & $\begin{array}{c}\text { Arriva } \\
\text { ls }\end{array}$ & Prices & $\begin{array}{c}\text { Arriva } \\
\text { ls }\end{array}$ & Prices \\
\hline January & 110 & 95.45 & 65.93 & 94.23 & 118.89 & 95.77 & 134.16 & $\mathbf{9 5 . 8 6}$ \\
\hline February & 80.06 & 97.41 & 52.19 & 95.22 & 91.64 & 98.2 & 69.06 & $\mathbf{9 7 . 9 5}$ \\
\hline March & 80.32 & 97.86 & 45.44 & 97.72 & 67.58 & 100.1 & 48.27 & $\mathbf{9 9 . 4 5}$ \\
\hline April & 90.61 & 104.81 & 58.63 & 103.85 & 41.52 & 107.48 & 31.67 & $\mathbf{1 0 5 . 8 8}$ \\
\hline May & 109.30 & 108.17 & 72.52 & 107.37 & 45.04 & 107 & 27.22 & $\mathbf{1 0 6 . 9 9}$ \\
\hline June & 67.01 & 102.23 & 46.68 & 104.84 & 40.66 & 102.5 & 22.36 & $\mathbf{1 0 2 . 2 3}$ \\
\hline July & 51.30 & 105.66 & 28.41 & 106.80 & 26.89 & 104.2 & 23.74 & $\mathbf{1 0 5 . 5 0}$ \\
\hline August & 42.32 & 103.08 & 80.99 & 104.77 & 28.00 & 101.8 & 55.02 & $\mathbf{1 0 0 . 7 6}$ \\
\hline September & 40.84 & 98.90 & 303.58 & 97.40 & 39.53 & 95.62 & 36.11 & $\mathbf{9 8 . 5 7}$ \\
\hline October & 188.30 & 92.79 & 250.95 & 94.10 & 375.94 & 92.56 & 347.58 & $\mathbf{9 1 . 6 8}$ \\
\hline November & 213.79 & 96.26 & 107.89 & 95.91 & 181.72 & 97.25 & 233.87 & $\mathbf{9 6 . 9 5}$ \\
\hline December & 135.11 & 97.37 & 86.78 & 97.79 & 142.58 & 98.05 & 170.94 & $\mathbf{9 8 . 1 7}$ \\
\hline Total & $\mathbf{1 2 0 0}$ & $\mathbf{1 2 0 0}$ & $\mathbf{1 2 0 0}$ & $\mathbf{1 2 0 0}$ & $\mathbf{1 2 0 0}$ & $\mathbf{1 2 0 0}$ & $\mathbf{1 2 0 0}$ & $\mathbf{1 2 0 0}$ \\
\hline
\end{tabular}

Table.2 Cyclical and irregular movements of time series data on arrivals of soybean in western Maharashtra

\begin{tabular}{|c|c|c|c|c|c|c|c|c|}
\hline \multirow{2}{*}{ Year } & \multicolumn{2}{|c|}{ Lasalgaon } & \multicolumn{2}{c|}{ Sangali } & \multicolumn{2}{c|}{ Kopargaon } & \multicolumn{2}{c|}{ Shrirampur } \\
\cline { 2 - 10 } & Arrivals & Prices & Arrivals & Prices & Arrivals & Prices & Arrivals & Prices \\
\hline $\mathbf{2 0 1 0}$ & 1.062 & 0.84 & 1.060 & 0.87 & 1.310 & 0.86 & 1.041 & $\mathbf{0 . 8 6}$ \\
\hline $\mathbf{2 0 1 1}$ & 1.178 & 0.94 & 0.947 & 0.94 & 1.130 & 0.93 & 0.794 & $\mathbf{0 . 9 3}$ \\
\hline $\mathbf{2 0 1 2}$ & 1.177 & 1.08 & 0.887 & 1.06 & 0.683 & 1.06 & 1.239 & $\mathbf{1 . 0 6}$ \\
\hline $\mathbf{2 0 1 3}$ & 1.034 & 1.21 & 0.829 & 1.17 & 0.586 & 1.18 & 1.046 & $\mathbf{1 . 1 8}$ \\
\hline $\mathbf{2 0 1 4}$ & 1.002 & 1.17 & 0.973 & 1.13 & 0.521 & 1.16 & 1.028 & $\mathbf{1 . 1 5}$ \\
\hline $\mathbf{2 0 1 5}$ & 0.786 & 1.11 & 1.286 & 1.09 & 0.457 & 1.1 & 0.358 & $\mathbf{1 . 1 1}$ \\
\hline $\mathbf{2 0 1 6}$ & 0.868 & 0.97 & 1.184 & 0.98 & 0.792 & 0.97 & 0.947 & $\mathbf{0 . 9 7}$ \\
\hline $\mathbf{2 0 1 7}$ & $\mathbf{0 . 9 7 7}$ & $\mathbf{0 . 9 1}$ & $\mathbf{1 . 0 5 0}$ & $\mathbf{0 . 9 4}$ & $\mathbf{1 . 3 5 7}$ & $\mathbf{0 . 9 2}$ & $\mathbf{1 . 2 1 5}$ & $\mathbf{0 . 9 3}$ \\
\hline
\end{tabular}

Table.3 Results of ADF test for soybean in western Maharashtra

\begin{tabular}{|c|c|c|c|}
\hline Market & $\begin{array}{c}\text { Level } \\
\text { (ADF) }\end{array}$ & $\begin{array}{c}\text { First } \\
\text { difference (ADF) }\end{array}$ & $\begin{array}{c}\text { Critical value } \\
(\mathbf{1} \%)\end{array}$ \\
\hline Lasalgaon & -2.2177 & -10.0848 & $\mathbf{- 3 . 4 8 6 5}$ \\
\hline Sangali & -2.0139 & -6.7767 & \\
\hline Kopargaon & -2.3117 & -8.7214 \\
\hline Shrirampur & $\mathbf{- 2 . 3 2 2 4}$ & $\mathbf{- 1 0 . 5 8 4 2}$ & \\
\hline
\end{tabular}


Table.4 Johansen's multiple co-integration analysis for soybean in Maharashtra

\begin{tabular}{|c|c|c|c|c|c|}
\hline $\begin{array}{c}\text { Hypothesized } \\
\text { No. of CE(s) }\end{array}$ & $\begin{array}{c}\text { Eigen } \\
\text { Value }\end{array}$ & $\begin{array}{c}\text { Trace } \\
\text { Statistic }\end{array}$ & $\begin{array}{c}\text { Critical } \\
\text { Value (5 } \\
\text { \%) }\end{array}$ & Prob. ** & $\begin{array}{c}\text { Number of Co- } \\
\text { integrating } \\
\text { equation CE(s) }\end{array}$ \\
\hline None $*$ & 0.24 & 59.75 & 47.86 & 0.0026 & Two \\
\hline At most 1* & 0.15 & 28.44 & 29.80 & 0.0710 & \\
\hline At most 2 & 0.04 & 9.60 & 15.49 & 0.3132 & \\
\hline
\end{tabular}

Trace test indicates 2 co-integrating eqn (s) at the 0.05 level.

Table.5 Pairwise granger causality test for major soybean markets with unidirectional price influence

\begin{tabular}{|c|c|c|c|}
\hline Null Hypothesis & F-Statistic & Prob. & Direction \\
\hline $\begin{array}{c}\text { LASALGAON does not Granger Cause } \\
\text { KOPARGAON }\end{array}$ & 1.29530 & 0.2779 & \multirow[t]{2}{*}{ Unidirectional } \\
\hline $\begin{array}{l}\text { KOPARGAON does not Granger Cause } \\
\text { LASALGAON }\end{array}$ & $14.8136 * * *$ & 2.E-06 & \\
\hline $\begin{array}{l}\text { SANGALI does not Granger Cause } \\
\text { KOPARGAON }\end{array}$ & 1.13833 & 0.3240 & \multirow[t]{2}{*}{ Unidirectional } \\
\hline $\begin{array}{l}\text { KOPARGAON does not Granger Cause } \\
\text { SANGALI }\end{array}$ & $22.9436 * * *$ & 4.E-09 & \\
\hline $\begin{array}{l}\text { SHRIRAMPURdoes not Granger Cause } \\
\text { KOPARGAON }\end{array}$ & 1.32723 & 0.2693 & \multirow[t]{2}{*}{ Unidirectional } \\
\hline $\begin{array}{l}\text { KOPARGAON does not Granger Cause } \\
\text { SHRIRAMPUR }\end{array}$ & $15.8223 * * *$ & 9.E-07 & \\
\hline $\begin{array}{l}\text { SANAGALI does not Granger Cause } \\
\text { LASALGAON }\end{array}$ & 2.16894 & 0.1191 & \multirow[t]{2}{*}{ Unidirectiona } \\
\hline LASALGAON does not Granger Cause SANGALI & $8.75605 * * *$ & 0.0003 & \\
\hline $\begin{array}{l}\text { SHRIRAMPUR does not Granger Cause } \\
\text { LASALGAON }\end{array}$ & 1.04270 & 0.3559 & \multirow[t]{2}{*}{ Unidirectional } \\
\hline $\begin{array}{l}\text { LASALGAON does not Granger Cause } \\
\text { SHRIRAMPUR }\end{array}$ & $5.88508 * * *$ & 0.0037 & \\
\hline $\begin{array}{l}\text { SHRIRAMPUR does not Granger Cause } \\
\text { SANGALI }\end{array}$ & $4.66593 * *$ & 0.0113 & \multirow[t]{2}{*}{ Unidirectiona } \\
\hline $\begin{array}{l}\text { SANGALI does not Granger Cause } \\
\text { SHRIRAMPUR }\end{array}$ & 2.18212 & 0.1176 & \\
\hline
\end{tabular}


Fig.1 Seasonal index of soybean prices in different markets in Maharashtra

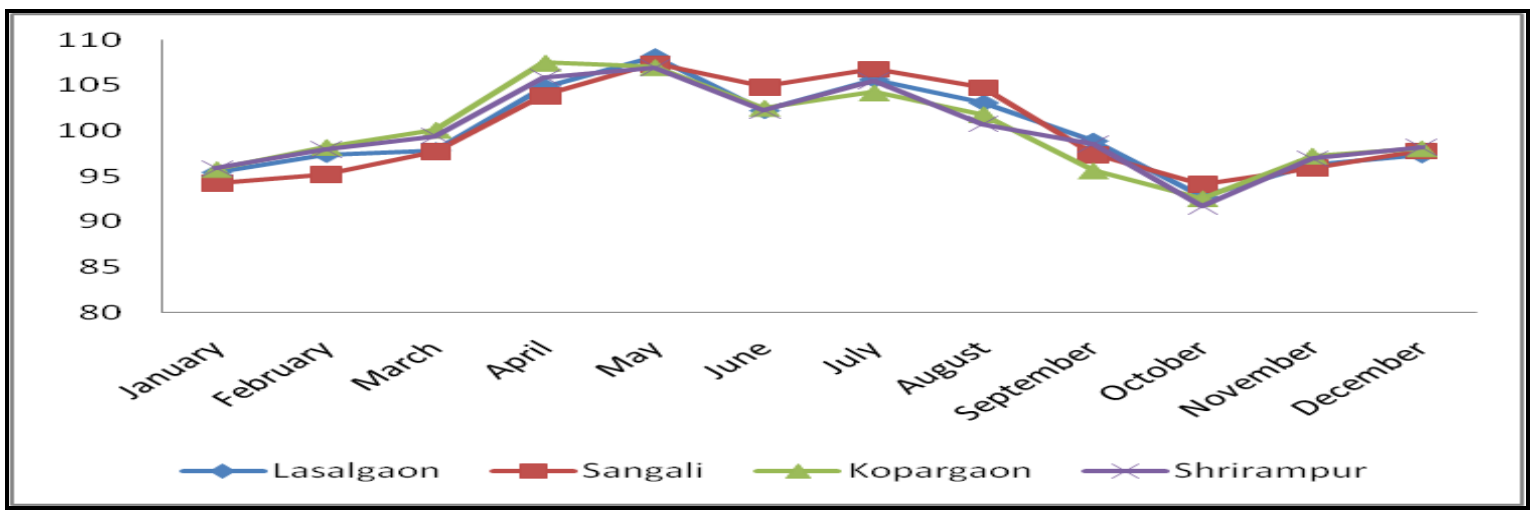

Fig.2 Seasonal index of soybean arrivals in different markets in Maharashtra

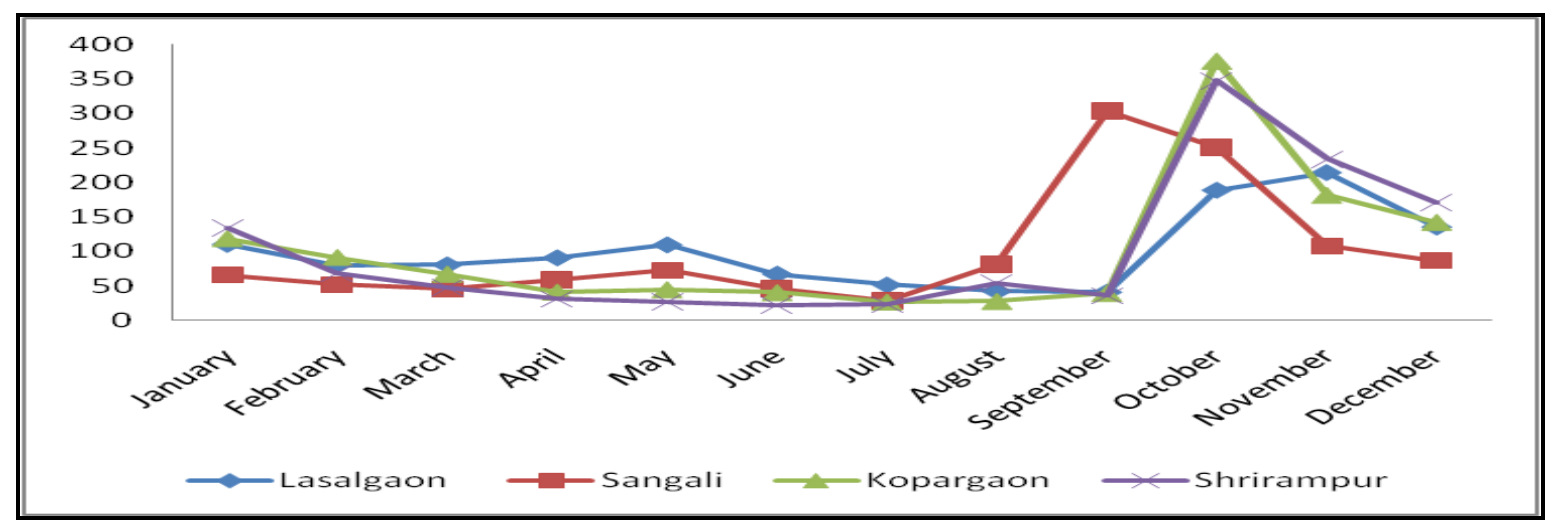

Fig.3 Cyclical index of soybean prices in different markets of Maharashtra

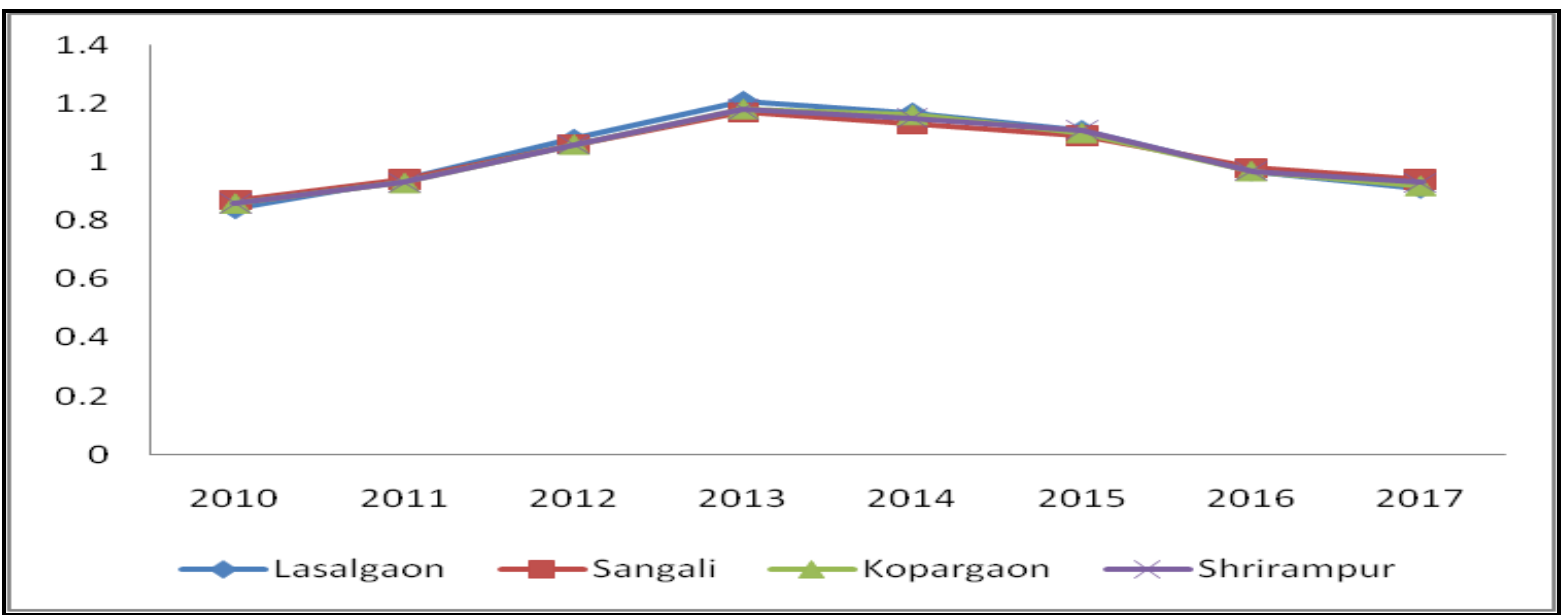

The seasonal indices of arrivals of soybean in selected markets were maximum during the months of October, November and December with few exceptions and in remaining months no specific trends were observed. While the price indices are moving around the average prices of soybean. However, inverse relationship between arrivals and prices was 
noticed with some exceptions. The cycles in the selected market for both arrivals and prices were found to be uneven. Thereby it implied that there was large fluctuation in arrivals and prices of soybean in the selected market.

The price series of soybean in all selected markets were non-stationary at one lag level. The selected soybean markets having long run equilibrium relationship and there existed cointegration among them.

The Johansen's Multiple Co-integration Analysis indicated that there existed a cointegration among the selected markets in Maharashtra.

The Pair wise Granger causality test for major markets in Maharashtra showed unidirectional price influence between Lasalgaon Kopargaon, Sangali- Kopargaon, ShrirampurKoprgaon, Sangali-Lasalgaon, ShrirampurLasalgaon and shrirampu-sangali market.

\section{References}

Bodade, V.M., Deshmukh, R.G.and Borkar, Prema (2017). Soybean price movement across major markets of Madhya Pradesh. Internat. Res. J. Agric. Eco. \& Stat., 8 (1): 162-169.

Chalwe, Sunga. 2017. An analysis of spatial market integration: A case of Zambian dry bean markets connected by informal trade to Tanzania and the Democratic Republic of Congo. Unpublished M.Sc. Thesis submitted to Stellenbosch University, South Africa.

Patil, V.K., Tingre, A.S. and D.J. Chaudhari. 2014. Soybean price movement across major markets of Maharashtra. International Research Journal of Agricultural Economics and Stastics, 6(1): 67-73.

Salmensuu, O. 2018. A potato market integration analysis for India. Journal of Review of Market Integration, 9(3): 111-138.

Shukla, D.N. and J. Rai. 2014. An economic study of behaviour of market arrivals and prices of onion, garlic and turmeric in selected markets of U.P. International Research Journal of Agricultural Economics \& Statistics, 5(2): 235-240.

\section{How to cite this article:}

Tambe, P. C., A. V. Gavali and Yadav, D. B. 2021. Price Behaviour of Soybean across Major Markets of Maharashtra. Int.J.Curr.Microbiol.App.Sci. 10(02): 3153-3160. doi: https://doi.org/10.20546/ijcmas.2021.1002.346 